\title{
PERAN CUSTOMER RELATIONS DALAM MENINGKATKAN KEPUASAN PELANGGAN PADA PT. INDOSAT CABANG LAMPUNG
}

\author{
Oleh: \\ Thabita Carolina ${ }^{1}$ \\ Neli Sari Wjayanti ${ }^{2}$ \\ Program Studi Ilmu Komunikasi, Universitas Tulang Bawang Lampung \\ e-Mail: thabitacarolina@gmail.com
}

\begin{abstract}
ABSTRAK
Dunia telekomunikasi sudah berkembang begitu pesatnya ditambah dengan keberadaan perusahaan serupa mengakibatkan daya saing dalam merebut pelanggan menjadi tugas yang begitu berat. Persaingan yang begitu tinggi mengakibatkan larinya pelanggan kepada perusahaan lain yang memiliki kualitas serupa. Tujuan penelitian ini adalah bagaimana customer relations dalam meningkatkan kepuasan pelanggan pada PT. Indosat cabang Lampung. Penelitian menggunakan analisa deskriptif kualitatif. Hasil penelitian ini adalah customer relations menunjukkan secara positif berpengaruh baik terhadap peningkatan loyalitas pelanggan.
\end{abstract}

Kata kunci: komunikasi, customer relations

\section{PENDAHULUAN}

Kepuasan konsumen yang telah diteliti dan didefinisikan oleh para ahli pemasaran, dapat disimpulkan bahwa kepuasan konsumen merupakan suatu tanggapan perilaku konsumen berupa evaluasi purna beli terhadap suatu barang atau jasa yang dirasakannya (kinerja produk) dibandingkan dengan harapan konsumen. Secara umum kepuasan atau ketidakpuasan konsumen merupakan hasil dari adanya perbedaan-perbedaan antara harapan dari para konsumen dengan kinerja yang dirasakan oleh konsumen tersebut. Kepuasan konsumen ini sangat tergantung pada persepsi dan harapan konsumen itu sendiri.

Era perkembangan teknologi saat ini membuat komunikasi antar manusia lebih mudah dan lebih cepat. Akses dalam berkomunikasi diinovasikan dalam segala bentuk yang mungkin tidak terbayangkan sebelumnya. Hal ini merupakan fokus utama dari setiap penyedia telepon seluler sebagai reaksi dari banyaknya permintaan pasar akan teknologi telekomunikasi yang lebih baik dari sebelumnya.

Adanya permintaan yang tinggi itu selama lima tahun terakhir, semakin banyak provider telepon seluler dengan berbagai macam produk yang bermunculan, dengan kualitas dan performasi masing-masing. Makin banyak perusahaan-perusahaan tersebut akan mempertajam tingkat persaingan yang dihadapi bagi perusahaanperusahaan yang menghasilkan jasa sejenis perkembangan dunia telekomunikasi yang semakin pesat dan persaingannya antar operator telepon seluler, para produsen tidak gegabah dalam menentukan kegiatan promosinya.

Persaingan akan semakin terbuka manakala muncul provider-provider baru dan tantangan semakin besar bagi para 
lama. Begitu besarnya mempengaruhi ketersediaan dalam suatu perusahaan untuk bisa bertahan, maka pasti berlebihan jika perusahaan operator telepon seluler bekeria maksimal guna mempertahankan dan bahkan menambah antrian pelanggannya. Dan itu adalah tugas Public Relation yang salah satu kegiatan adalah Customer Relations (hubungan dengan pelanggan). Humas yang membawahi unit kerja Hubungan Pelanggan, harus memiliki latar belakang kerja yang baik dalam pelaksanaan setiap kegiatannya harus berorientasi pada tujuan.

Perusahaan jasa telekomunikasi yang menyediakan produk berbasis teknologi GsM di indonesia ada berbagai macam, antara lain PT. Indosat dengan kartu GSM yaitu Matrix Mentari, IM3 dan kartu cDMA starone. Bentuk program loyality pada pelanggan kartu Matrix adalah layanan berkembang menjadi kartu Matrix ke Auto, dimana pelanggan yang tersedia tidak ada abonemen pemakaiannya bisa sesuai keinginan pengguna dan bisa di isi ulang sesuai kebutuhan.

Keunggulan Matrix paket Auto ini sangat fleksibel bisa di isi ulang agar bisa terkontrol untuk pemakaiannya. Selain itu harganya yang terjangkau, aksesbilitas, mutu prima dan jangkauan yang luas. PT. Indosat cabang Lampung, secara maksimal terus mengusahakan berbagai cara untuk meningkatkan kualitas hubungan pelanggan dengan cara seperti, komunikasi tatap muka (temu pelanggan).

PT. Indosat cabang Lampung juga mempublikasikan undian- undian bagi pelanggannya (promotainment). Disamping itu PT. Indosat cabang Lampung terus meningkatkan kualitas dan kuanlitas pelayanannya. Hal mendasar yang perlu dilakukan dalam Customer Relations adalah harus melihat kebutuhan dan kepuasan pelanggan, karena sesungguhnya kepuasan pelanggan yang secara keseluruhan akan meningkatkan loyalitas pelanggan.

Berdasarkan pokok pikiran diatas maka penulis tertarik untuk melakukan penelitian mengenai Peran Customer Relations dalam Meningkatkan Kepuasan Pelanggan oleh PT. Indosat cabang Lampung.

\section{METODE PENELITIAN}

Penelitian ini menggunakan metode deskriptif yaitu suatu penelitian yang bertujuan menggambarkan secara tepat sifat-sifat suatu individu, gejala atau keadaan tertentu dalam suatu tempat. Deskriptif artinya data yang dikumpulkan adalah berupa kata-kata, gambar dan bukan angka-angka (Moleong 2010: 11). Adapun teknik pengumpulan data dilakukan dengan wawancara kepada sejumlah pelanggan dan pengguna kartu matrik dari PT. Indosat.

Teknik tersebut dilakukan dengan cara tanya jawab antara peneliti dan narasumber yang dianggapa relevan dengan penelitian ini. Wawancara ini dilakukan secara tebuka serta mendalam agar dapat memberikan kesempatan kepada narasumber tersebut dalam rangka menjawab secara bebas, hal ini bertujuan untuk memperoleh pengertian maupun penjelasan lebih mendalam tentang realita dari objek yang akan diteliti tersebut.

Populasi dan sampel dalam penelitian ini adalah beberapa pelanggan yang menggunakan kartu Matrix paket auto pada PT. Indosat. Menurut Mohamad Panbuditika (1996:32) populasi adalah himpunan individu objek yang banyaknya terbatas atau tidak terbatas. Berdasarkan populasi diatas dapat dijelaskan bahwa populasi adalah sekelompok individu atau 
objek jumalh terbatas atau tidak terbatas jumlahnya dalam suatu wilayah terbatas.

Dikarenakan keterbatasan waktu dan dana dalam penelitian ini maka peneliti mengambil populasi dari pelanggan yang dating ke acara temu pelanggan yaituu dengan mengambil jumlah 20 pelanggan.

Sampel menurut Pabudi Tika (1996:33) adalah sebagian dari objek atau individu-individu yang mewakili suatu populasi. Sedangkan menurut Suharsimi (1986:34) sampel adalah sebagian/ wakil populasi yang akan diteliti. Berdasarkan pernyataan diatas maka yang dimaksud sampel adalah bagian dari populasi yang akan dijadikan objek dari suatu penelitian.

Proses wawancara tersebut dibantu dengan panduan wawancara sebagai alat bantu penulis dalam penyajian data. Selain wawancara, teknik pengumpulan data juga dilakukan dengan cara observasi di lokasi yaitu di PT. Indosat cabang Lampung.

\section{Komunikasi}

Komunikasi secara sederhana dapat diartikan sebagai penyampaian pesan dari komunikator ke komunikan untuk tujuan tertentu melalui saluran-saluran komunikasi. Ada beberapa pendapat para ahli tentang komunikasi :

1. Carl Hovland mengatakan komunikasi adalah sebagai suatu proses dimana seseorang atau komunikator mengoper perangsang biasanya dengan lambing-lambang bahasa untuk mengubah tingkah laku individu lain (Meinanda, 1985:9).

2. Astrid S. Susanto (1979: 32) mengatakan bahwa pengertian komunikasi adalah kegiatan yang merupakan reaksi terhadap persepsi dan usaha realisasi atau penghindaran dari ide-ide.

Sedangkan Charles Cooley memberikan batasan-batasan bahwa komunikasi sebagai mekanisme yang menyebabkan semua lambing pikiran, bersamasama dengan alat untuk menyarkannya dalam ruang dan waktu (Onong 1992:60).

3. Onong Uchjana Effendy (1992:5) komunikasi adalah peoses penyampaian pesan oleh seseorang kepada orang lain untuk member tahu atau menubah sikap, pendapat atau perilaku baik langsung sevara lisan maupun tak langsung melalui media.

Sehingga kalau dirumuskan maka pengertian komunikasi itu berarti suatu proses pemberitahuan mengenai suatu keterangan dari sumber keterangan penerimaan yang memungkinkan keduanya dapat berpartisipasi secara bersama. Proses semacam ini dapat dilakukan melalui alat perantara seperti radio, televisi, telepon, telegram, surat kabar, seminar, diskusi panel, symposium, isyarat dan tanda-tanda tertentu dan sebagainya (Miftah Toha, 1993:109).

Setiap komunikasi mengandung usaha mengajak, melibatkan diri atau orang lain. Proses komunikasi didahului oleh suatu proses seleksi penyaringan dan susunan berdasarkan factor-faktor yang diingat, diinginkan atau tidak diinginkan oleh komunikator. Dengan demikina komunikasi merupakan masalah yang sangat pokok dalam proses setiap kegiatan didalam suatu organisasi dalam rangka mencapai tujuan.

Harold D Laswell secara rinci mengemukakan fungsi-fungsi komunikasi adalah sebagai berikut: 
1. Penjajakan atau pengawasan lingkungan (surveillance of the environment)

2. Menghubungkan bagian-bagian terpisah dari masyarakat untuk menanggapi lingkungannya (un of the part society in responding the environment)

3. Menurunkan warisan social dari generasi ke generasi berikutnya ( Transmission of social heritage). (Nurdin 2004:16)

Setelah memahami arti dan fungsi komunikasi, sehingga dapat dilihat komponen-komponen komunikasi :

1. Komunikator

Dalam komunikasi setiap orang atau kelompok dapat menyampaikan pesan-pesan komunikasi sebagai suatu proses dimana komunikator dapat menjadi komunikan begitu sebaliknya, diantaranya:

a. Penampilan

Seorang komunikator harus menyesuaikan diri dengan lingkungan dan komunikan, penempilan sangat sesuai dengan tata karma dengan memperhatikan keadaan, waktu dan tempat.

b. Penguasaan masalah

Seorang komunikator harus betul-betul menguasai masalah, jika tidak maka setelah proses komunikasi berlansung akan menimbulkan ketidak percayaan terhadap

komunikator. Didalam suatu proses komunikasi timbale balik yang lebih menguasai masalah akan cenderung memenangkan tujuan komunikasi. c. Penguasaan bahasa

Komunikator harus menguasai bahsa dengan baik, komunikator mutlak menguasai istilah-istilah umum yang digunakan oleh lingkungan tertentu, tanpa penguasaan bahasa secara baik dapat menimbulakn ketidak percayaan terhadap komunikator

2. Pesan

Pesan adalah keseluruhan dari apa yang disampaikan komunikator. Pesan ini mempunyai inti yang sebenarnya menjadi pengarah didalam usaha mencoba mengubah sikap dan tingkah laku komunikan. Pesan dapat mengupas berbagai segi, namun inti pesan dari komunikan akan selalu mengarah kempada tujan akhir kounikan itu antara lain:

a. Penyampaian pesan, melalui lisan, face to face, langsung, menggunakan media, saluran.

b. Bentuk pesan : informative, persuasive, koersif

Informative : bersifat memberikan keteranganketerangan kemudian komunikan mengambil kesimpulan dan keputusn sendiri. Pesan informative justru lebih berhasil ketimbang persuasive.

Persuasive : berisikan bujukan yakni membangkitkan pengertian dan kesadaran manusia bahwa apa yang akan disampaikan akan memberikan perubahan sikap, tetapi berubahnya atas kehendak sendiri/ kesadaran sendiri.

Koersif : penyampaian pesan yang bersifat memaksa dan 
dengan menggunakan sanksisanksi apabila tidak dilaksanakan.

3. Komunikan adalah orang yang menerima berita atau informasi

4. Media

Saluran penyampaian pesan biasa juga disebut channel. Media komunikasi dapat dikategorikan dalam dua bagian:

a. Media umum adalah media yang dapat digunakan oleh segala bentuk komunikasi

b. Media massa adalah media yang digunakan untuk komunikasi misal

5. Efek

Adalah hasil akhir dari suatu komunikasi yakni sikap dan tingkah laku orang, sesuai atau tidak sesuai dengan yang kita inginkan (Meinanda 1986:30-33).

\section{Customer Relations}

Customer relations menurut Onong Uchjana Effendy adalah hubungan dengan pelanggan yaitu komunikasi yang dilakukan timbal balik antara suatu perusahaan yang diwakilkan oleh petugas humas dengan pelanggan dalam rangka membina hubungan yang akrab dilandasi oleh asas saling pengertian dan saling percaya (1989:85).

Customer relations menurut Rosadi Rusalan adalah bagaimana membarikan pelayan yang prima kepada pelanggan sehingga terciptany kepuasan dan menumbuhkan kepercayaan pelanggan (1990:260). Sukses besar yang diraih oleh sebuah perusahaan disebabkan oleh pelanggan, bukan oleh penjualan itu sendiri.

Setiap barang atau jasa dapat saja dijual satu kali kepada pembeli akan tetapi sebuah perusahaan dinilai sukses kalau bias meningkatkan jumlah langganan yang membeli berulang kali. Demikian kata Lew Hahn seorang pengusaha Amerika.

Perusahaan yang mempunyai pelanggan tetap harus mempertahankan pelangannya jangan sampai pindah menjadi pelanggan perusahaan lain. Pada dasarnya customer relations PT Indosat adalah memberikan pelayanan yang terbaik dan memperkenalkan jasa-jasa yang ada di PT Indosat. Adapun tugas dan fungsi seorang petugas customer relations adalah:

1. Menentukan apakah konsumen atau para pelanggan memikirkan dan membicarakan kebijaksanaan, tindakan produk atau pelayanan perusahaan.

2. Meningkatkan pelayanan konsumen atau pelanggan dengan pelayanan yang lebih memuaskan atas dasar keluhan dengan analisis keluhan. Untuk mengetahui penyebab keluhan itu dengan memperbaiki kekurangan dalam operasi prosedur atau kebijaksanaan untuk mencegah keluhan-keluhan tersebut.

3. Menjawab pertanyaan konsumen yang berhbungan dengan produk pelyananan dan pemanfaatannya.

4. Memperoleh penerimaan tentang produk dan pelyanan perusahaan oleh public pemakai.

PT. Indosat sampai saat ini selalu berupaya meningkatkan kualitas pelayanan kepada pelanggannya melalui konsep pelayanan. Konsep pelayanan yang paling baik adalah dengan menggunakan kiat service of excellence, diaman PT Indosat berupaya untuk memberikan rasa kepuasan dan menumbuhkan kepercayaan kepada para pelanggan. 


\section{HASIL DAN PEMBAHASAN}

Memenangkan strategi persaingan dalam bisnis melalui kiat pelayanan yang prima tidaklah cukup melainkan bagaimana cara perusahaan melayani sebaik mungkin sehingga menimbulkan persepsi positif dari para pelanggan. Maka terlihat secara intens dukungan kualitas personil yaitu caranya merespons berperilaku sopan dan santun, memiliki pengetahuan dan keterampilan khusus yang integrasi dari seluruh factor proses pelayanan prima.

Fungsi service of excellence adalah menjaga konsistensi dalam hal kualitas pelayanan, tidak hanya sekedar memuaskana pelanggan dalam arti umum, tetapi juga harus memiliki kualitas dalam penawaran dan pelayanan yang unggul sepanjang waktu.

Tujuan dari service of excellence yang dilakukan praktisi PR adalah :

1. Menciptakan image positif perusahaan

2. Mendorong pelanggan untuk kembali

Artinya setiap transaksi dengan pelanggan bertujuan membuatnya kembali lagi melalui keramah tamahan, perhatian yang tulus, mengesankan dan pelayanan yang memuaskan.

3. Menciptakan hubungan yang saling percaya

Artinya menunjukkan pada pelanggan bahwa kita mengerti apa yang mereka inginkan, mau menerima dan merasa terlibat dalam persoalan mereka sehingga tercipta suatu hubungan saling percaya melalui cara dan sikap seperti :

a. Terbuka
Menciptakan suasana akrab, menanyakan sesuatu yang berkesan dan mohon maaf atas keterlambatan.

b. Thanks

Mengucapkan terimakasih atas kedatangannya.

c. Let them talk Membiarkan pelanggan berbicara dan mengemukakan keperluan dan keinginannya.

d. Minta izin untuk megajukan pertanyaan dan menjelaskan bahwa dengan memahami masalah kebutuhannya pelanggan mendapatkan solusi terbaik.

Adapun program kegiatan cutomer relations dalam meningkatkan loyalitas pelanggan PT Indosat cabang Lampung dilakukan melalui saluran/ channel adalah sebagai berikut :

\section{Personal Contact}

Unsure yang paling penting dalam hubungan ini adalah perlakuan terhadap perorangan yang berhubungan dengan badan atau perusahaan. Tidaklah cukup hanya dengan memberikan penjelasanpenjelasan saja kepada seseorang baik lisan maupun tilisan yang peling penting adalah perlu adanya perhatian terhadap reaksi dari individu. Petugas PR yang langsung berhadapan dengan karyawan haruslah bersikap ramah, sopan, santun dan selalu siap mendengarkan apa yang dikatakan dan ditanyakan public. Jika personal kontak ini dilakukan melalui surat maka dengan segera surat-surat tersebut harus ditanggapi dengan memberikab jawaban atas pertanyaan public. 
2. Publikasi media

Media yang disiarkan disurat kabar, majalah, TV maupun radio. Publisitas biasanya berupa press realese dimana berisikan teks sambutan, laporan, wawancara, rapat, kejadian-kejadian yang dimuat dalam mass media baik elektronik maupun cetak. Tidak lupa harus memperhatikan $5 \mathrm{~W}+1 \mathrm{H}$

3. Calendar event

Acara rutin yang dilaksanakan pada hari, bulan, tahun tertentu secara periodic dan berulang-ulang diselenggarakan sepanjang tahun kalender.

4. Direct mail

Biasanya berupa bulletin berkala yang dikirim kepada pelanggan berisi informasi terbaru tentang perusahaan berkaitan dengan produk dan jasa yang dihasilkan. Pelayanan-pelayanan pelanggan tersebut dapat berupa ucapan hari raya, ulang tahun maupun tahun baru.

5. Promotainment

Tujuan dari promotainment adalah mengenalkan produk dan jasa yang dihasilkan oleh suatu perusahaan yang dikemas secara menarik dan menghibur. Dalam hal ini bias melibatkan pelanggan untuk ikut berpartisipasi dalam kegiatan ini.

6. Melakukan kegiatan pameran

Adalah kegiatan yang menunjukkan sesuatu kepada orang banyak mengenai kelebihan dan keunggulan yang dimiliki.

7. Merancang dan membuat souvenir sebagai alat penjalin hubungan perusahaan dengan pihak eksternal/ pelanggan. Dapat dikirimkan atau diberikan dalam bentuk parcel atau ketika pelanggan melakukan pembayaran atas produk/ jasa yang digunakan pelanggan.

\section{KESIMPULAN}

Berdasarkan hasil penelitian analisa pembahas dapat disimpulkan bahwa customer relations menunjukkan secara positif berpengaruh baik terhadap peningkatan loyalitas pelanggan. Pelanggan yang loyal pada PT. Indosat adalah pelanggan yang mau menyampaikan keluhannya kepada perusahaan dalam hal ini PT. Indosat. Selain itu para pelanggan yang loyal juga menyampaikan asumsi untuk memperbaiki kinerja perusahaan itu sendiri. Secara otomatis pelanggan akan menjadi pelanggan yang loyal jika kinerja perusahaan baik.

PT. Indosat selalu meningkatkan pelayanan konsumen atau pelanggan dengan pelayanan yang lebih memuaskan atas dasar keluhan. Untuk mengetahui penyebab keluhan itu dengan memperbaiki kekurangan dalam operasi prosedur atau kebijaksanaan untuk mencegah keluhankeluhan tersebut. Mengembangkan program-program custumer relations yang efektif sehingga loyalitas pelanggan akan tercipta.

\section{DAFTAR PUSTAKA}

A.A Anwar Prabu Mangkunegara. 1988. Perilaku Konsumen. PT. Eresco. Bandung

AB. Susanto. 1996. Kepurusan dan Loyalitas Konsumen. Bisnis Indonesia. Jakarta

AW. Widjaya. 1986. Komunikasi dan Hubungan Masyarakat.

F. Rahmadi. 1992. PR dalam Teori dan Praktek. Gramedia. Jakarta 
Onong Uchjana Effendy. 2000. Human Relations dan Public Relations. Remaja Rosda Karya. Bandung

Hubungan Masyarakat Prinsip Kasus dan Masalah Dua. Remaja Rosdakarya. Bandung
Timothy R.V. Foster. Customer Care. 2004. Gramedia. Jakarta

\section{Sumber lain:}

http://www.indosat.com 